\title{
DID THE MEGAFAUNA RANGE TO 4300 BP IN SOUTH AMERICA?
}

\begin{abstract}
Alberto L Cione ${ }^{1} \bullet$ Aníbal J Figini ${ }^{2}$ Eduardo P Tonni ${ }^{1}$
ABSTRACT. A date of $4300 \pm 90 \mathrm{BP}$ for extinct megafauna in Argentina is discussed. The fossil remains come from the Guerrero Member (area) of the Luján Formation near the city of Luján, Buenos Aires Province. The age of the top of the Guerrero Member is constrained by more than 60 radiocarbon dates obtained from the overlying Río Salado Member of Luján Formation, Las Escobas Formation, and Puesto Callejón Viejo Soil, most of them older than 4300 BP. In view of its low collagen content, the ${ }^{14} \mathrm{C}$ measurement of bone sample from Luján should not be accepted uncritically. Because of the poor bone preservation and the possible introduction of "young" contaminants that were not completely eliminated, the ${ }^{14} \mathrm{C}$ date of $4300 \pm$ $90 \mathrm{BP}$ is not reliable. Both biostratigraphic and ${ }^{14} \mathrm{C}$ dating evidence indicates that the date of $4300 \mathrm{BP}$ for the last representative of extinct megafauna in South America is unsupported.
\end{abstract}

\section{INTRODUCTION}

Many large mammals that inhabited South American terrestrial environments became extinct at the end of the Pleistocene and beginning of the Holocene. To explain these extinction events, the youngest records of the involved taxa must be accurately dated, especially because the causes of the extinction are not completely elucidated (see different views in Martin and Klein 1984; MacPhee 1999).

Among those that disappeared were such important groups as glyptodonts and mylodonts (Cione and Tonni 1999; Cione et al. 1999). Recently, Rosello et al. (1999) reported a date of $4300 \pm 90 \mathrm{BP}$ for the putatively youngest remains of the glyptodont Glyptodon clavipes and indeterminate ground sloths of the family Mylodontidae. The material was processed in the Radiocarbon Laboratory of Department of Geology, National Taiwan University (Taipei, Taiwan). No number was reported for the date. In this contribution, we discuss this unusually young age for these extinct representatives of the South American megafauna.

\section{Provenance of the Material}

The material of Glyptodon clavipes (in situ) and mylodontids was found in sediments of the Luján Formation in the Río Luján valley near Mercedes, Buenos Aires province, Argentina (Rosello et al. 1999; Figure 1).

Rosello et al. (1999:106) only recognized the Luján and "Platense" Formations. Actually, the Luján Formation is formally divided into three members (Fidalgo et al. 1973; Dillon and Rabassa 1985): La Chumbiada, Guerrero, and Río Salado (from oldest to youngest; Figure 2). The Río Salado Member (area) is the "Platense" of old authors. According to the data given by Rosello et al. (1999), the material was obtained from levels of the Guerrero Member.

In the Pampean region, the Luján Formation was deposited in the river valleys while the late Pleistocene to Holocene La Postrera Formation was deposited in the divides (Fidalgo et al. 1973; Fidalgo 1979). The Guerrero Member is overlain by the Río Salado Member of Luján Formation but also by the marine Las Escobas Formation (Fidalgo et al. 1973; Figure 2). The marine mid Holocene sediments of the Las Escobas Formation crop out in eastern Buenos Aires Province 0-5 m above current sea level (Fidalgo et al. 1973; Fidalgo 1979, 1983). The Río Salado Member is correlated at least in part with the middle Holocene Las Escobas Formation marine beds (Fidalgo 1979). The tchernozoid Puesto Callejón Viejo Soil (Fidalgo 1983) frequently occurs at the top of the Guerrero Member.

\footnotetext{
${ }^{1}$ Departamento Científico Paleontología Vertebrados, Facultad de Ciencias Naturales y Museo, 1900 La Plata, Argentina. Email: acione@museo.fcnym.unlp.edu.ar; eptonni@museo.fcnym.unlp.edu.ar.

${ }^{2}$ LATYR-CIG Facultad de Ciencias Naturales y Museo, 1900 La Plata, Argentina
} 


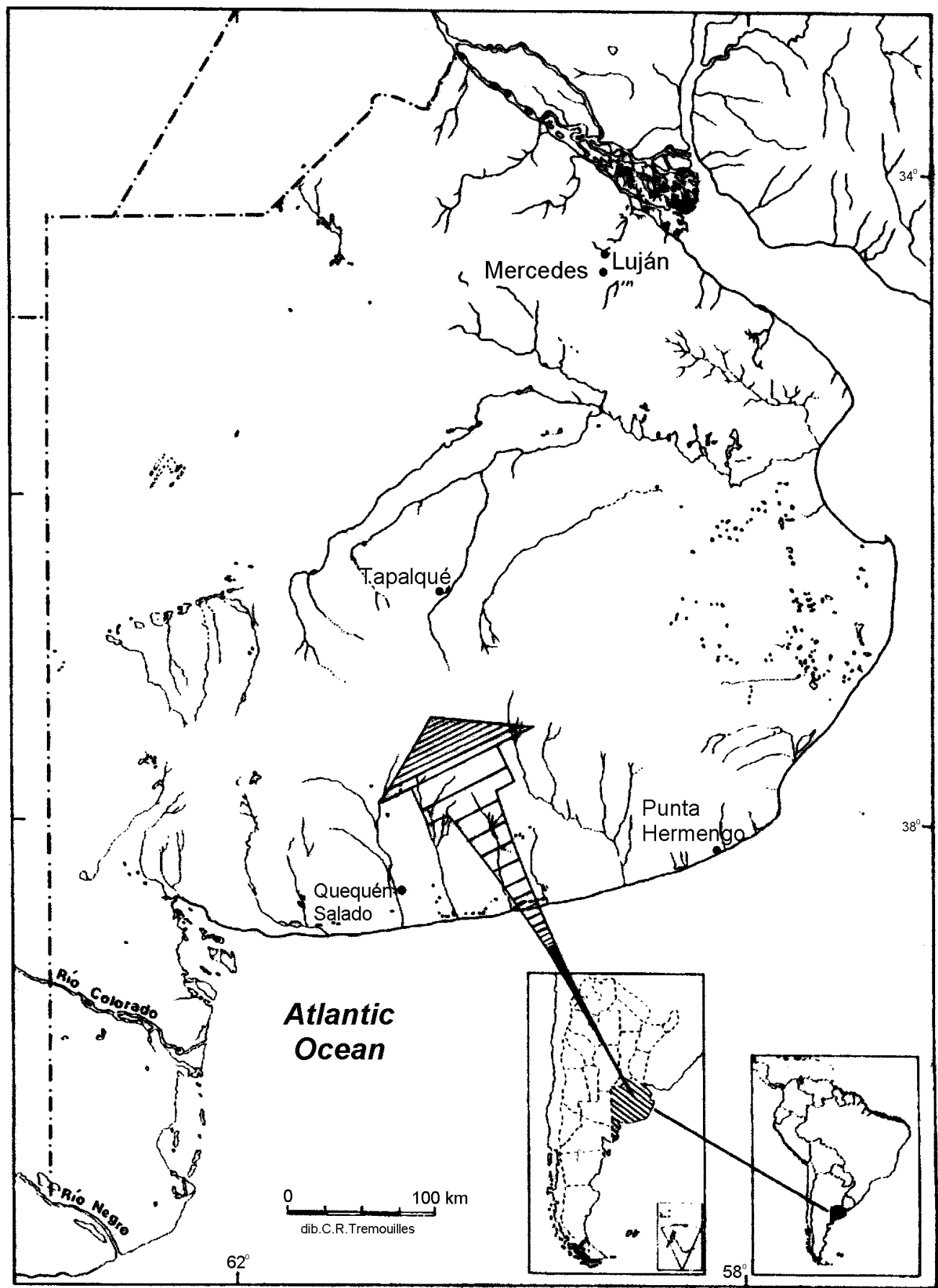

Figure 1 Map of Pampean area of Argentina depicting localities mentioned in text 


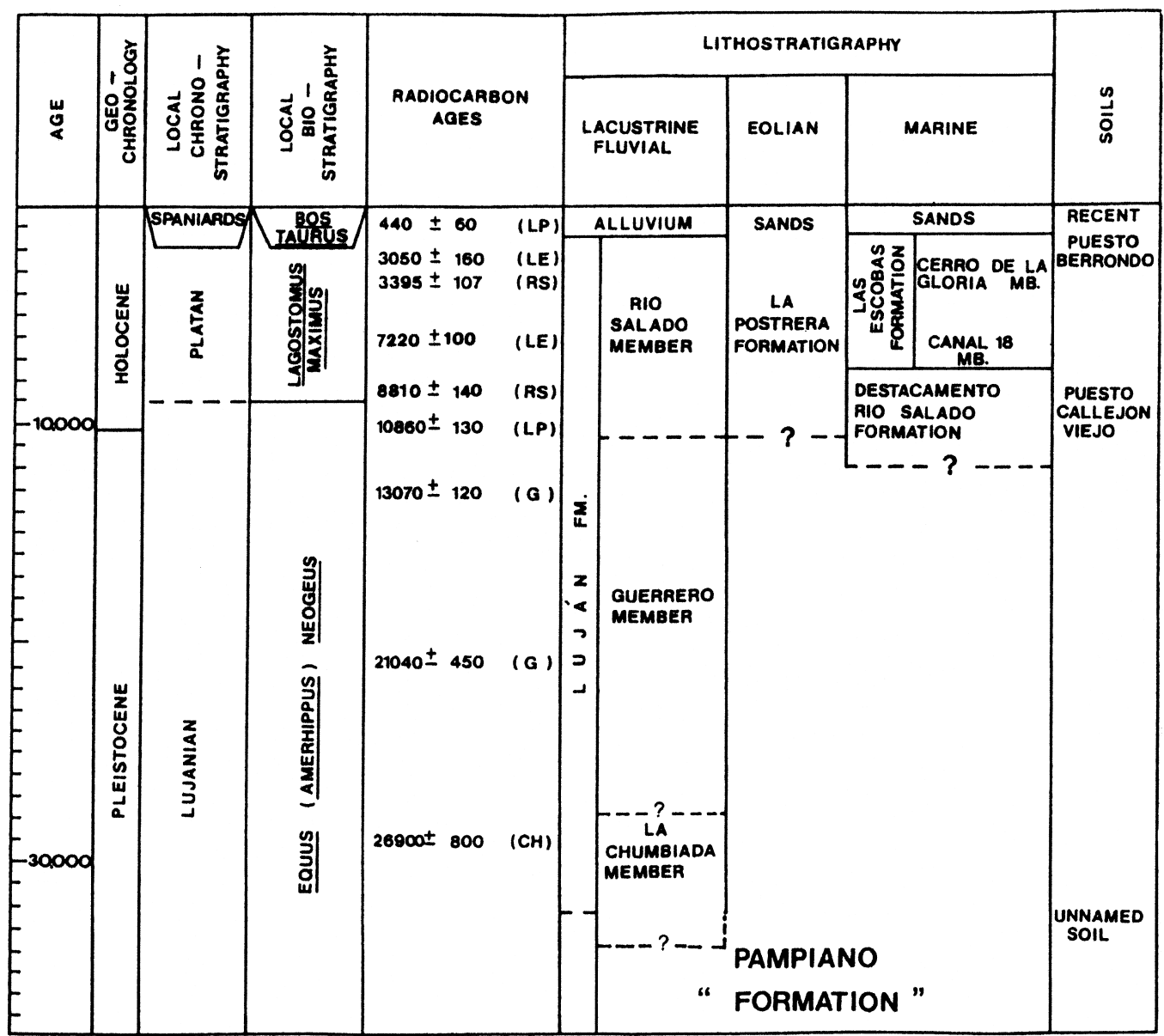

Figure 2 Diagram showing late Pleistocene and Holocene continental and marine lithostratigraphic units and paleosoils of the Pampean area (Fidalgo et al. 1991), the local time and biostratigraphic scales (Cione and Tonni 1995a,1995b) and some radiocarbon dates

Using the rich fossil record, and based on old local stratigraphic views, we have devised a biostratigraphic scheme for the Pampean area (Cione and Tonni 1995a, 1995b, 1996, 1999). The uppermost units are the Equus (Amerhippus) neogeus and Lagostomus maximus biozones (Figure 2).

The Equus (Amerhippus) neogeus Biozone is the local biostratigraphic basis for the recognition of the Lujanian Stage/Age (non Ameghino 1889; non Pascual et al. 1965; Cione and Tonni 1999). The biozone encompasses the La Chumbiada and Guerrero Members. We had suggested that the base of the biozone corresponded to the base of La Chumbiada Member. However, the occurrence of Equus (Amerhippus) neogeus in marine sediments assigned to the last interglacial (about $0.13 \mathrm{Ma}$ ) at the lower valley of the Río Quequén Salado (southern Buenos Aires province; Figure 1), showed that the base of the biozone was older (Pardiñas et al. 1996). In this biozone, the last representatives of the extinct megafauna were recorded.

The Lagostomus maximus biozone is the local biostratigraphic basis for the Platan Stage/Age (Cione and Tonni 1999). Their base coincides with that of the Río Salado Member and also encompasses 
more recent strata. Only living species are recorded in this biozone with the exception of some recently extinct mammal species (v.gr. Dusicyon avus extinct by $1450 \mathrm{BP}$ ).

\section{Age of the Guerrero Member}

The lower part of the Guerrero Member of the Luján Formation yielded six dates between $21040 \pm$ 450 and 17,680 $\pm 400 \mathrm{BP}$, based on carbonate, collagen, and molluscan shells (Huarte et al. 1988; Figini et al. 1995). However, Figini et al. (1995) calculated that those dates obtained from molluscan shells are $1100 \pm 140$ too old due to the reservoir effect. This assumption may be correct, given that bone collagen from the upper beds has yielded a younger date (13070 $\pm 120 \mathrm{BP}$; Tonni 1990).

The age of the Guerrero Member is not only calculated by the dates from the unit but also is constrained by numerous dates obtained from the overlying Río Salado Member of Luján Formation, Las Escobas Formation, and Puesto Callejón Viejo Soil.

Eleven ${ }^{14} \mathrm{C}$ ages based on molluscan shells and total organic matter were obtained from the Río Salado Member in sections at the arroyo Tapalqué (central Buenos Aires province; Figure 1) ranging between $9710 \pm 110$ and $8810 \pm 140 \mathrm{BP}$ (Figini et al. 1995; Zárate et al. 1995). These dates seem too old in comparison with many other dates based on bone collagen from the lower part of the La Postrera Formation, which includes extinct mammals of the Equus (Amerhippus) neogeus Biozone. However, when corrected to account for the reservoir effect, these ages get closer to those of La Postrera Formation.

Fidalgo (1992) suggested that the Puesto Callejón Viejo Soil represents the Pleistocene-Holocene boundary in the Pampean region. One date from organic matter from the Puesto Callejón Viejo Soil yielded a date of $9000 \pm 70$ (Zárate et al. 1995). ${ }^{14} \mathrm{C}$ dates from dispersed organic matter, calcium and mollusc shells, from levels which are correlated with the Puesto Callejón Viejo Soil, gave dates ranging from $10070 \pm 140$ to $8940 \pm 130 \mathrm{BP}$ (Fidalgo et al. 1986; Bonadonna et al. 1995; Figini et al. 1998). However, the correlation of these beds with the paleosoil remains to be confirmed.

Forty-six dates were obtained from mollusc shells and marine mammal bones of the Holocene Las Escobas Formation. They range from $7890 \pm 343$ to $3050 \pm 160$ BP (Figini et al. 1978; Carbonari et al. 1980; Fidalgo et al. 1981; Huarte et al. 1983; Gómez et al. 1985, 1988; Carbonari et al. 1987; Fasano et al. 1987; Figini 1992; Colado et al. 1995). The youngest dates correspond to upper levels and the older to lower levels.

\section{Quality of the Date of Rosello et al. (1999)}

The chemical composition of a recent bone includes approximately $20 \%$ proteins, mainly collagen. Modifications in the organic matter composition in a fossil bone are occasioned by 1) the large surface (larger than $100 \mathrm{~m}^{2} / \mathrm{g}$ ) and porous structure that makes it an excellent medium for adsorption and precipitation of dissolved and colloidal particles of humic material and other molecules; this material, mobilized in groundwater, derives from modern soils and lacustrine-bog deposits (Arlanov and Svezhentsev 1993); and 2) protein content diminution due to collagen dissolution or destruction. In extreme cases fossil bones are stripped of their collagen.

Reliable ${ }^{14} \mathrm{C}$ dating using fossil bones (Hedges and van Klinken 1992) is based on samples with an adequate collagen fraction. Samples must fulfill the following conditions: no exogenous organic matter, enough material, and well-preserved bone with more than $4 \%$ collagen.

T K Liu (one of the co-authors of the paper by Rosello et al. 1999) communicated to us that samples from Luján weighted $1.8 \mathrm{~kg}$. Using the methodology of Longin (1971), Rosello et al. (1999) 
obtained "collagen" with an equivalent weight to $1.12 \mathrm{~g}$ of carbon. This means that the bone had approximately $0.12 \%$ of collagen.

However, a bone that includes less than $0.5 \%$ of collagen is very poorly preserved, may not include original collagen, and probably is highly contaminated (Staffort et al. 1987; Hedges and van Klinken 1992). A low collagen content in the sample implies that a larger quantity of material is needed to be processed and a larger exogenous organic matter needs to be eliminated. With the collagen loss, a larger chemical degradation of remnant protein will occur. This provokes problems in isolating, purifying, and characterizing bone collagen, and also makes it impossible to detect and characterize exogenous organic matter in the obtained "collagen." In this case, ${ }^{13} \mathrm{C}$ determination is not enough.

\section{DISCUSSION AND CONCLUSION}

The fossil remains described by Rosello et al. (1999) come from the Guerrero Member and are included in the Equus (Amerhippus) neogeus Biozone. They obtained a ${ }^{14} \mathrm{C}$ date of $4300 \pm 90 \mathrm{BP}$. However, the age of the top of the Guerrero Member is constrained by more than 63 dates obtained from the overlying Río Salado Member of the Luján Formation, Las Escobas Formation, and Puesto Callejón Viejo Soil, most of them older than 4300 BP.

Additionally, in view of its low collagen content, the bone sample from Luján should not have been submitted for dating. The ${ }^{14} \mathrm{C}$ date of $4310 \pm 90 \mathrm{BP}$ is not reliable because of poor bone preservation and the possible introduction of "young" contaminants that were not completely eliminated in pretreatment (Arslanov and Svezhentser 1993). A small amount of "modern" organic matter (0 BP) can make an old specimen yielding little collagen appear much younger (Follestad and Omosi 1979). A sample with an actual age of 100,000 BP with a contamination of $1 \%$ of "modern" carbon gives a ${ }^{14} \mathrm{C}$ age of $37,000 \mathrm{BP}$.

Consequently, the biostratigraphic and the isotope dating evidence indicates that the date of $4300 \mathrm{BP}$ for the last megafauna representation in South America is unsupported.

\section{ACKNOWLEDGMENTS}

The authors would like to thank the following institutions: Consejo Nacional de Investigaciones Científicas y Técnicas, Comisión de Investigaciones Científicas de la Provincia de Buenos Aires, Agencia Nacional de Promoción Científica y Tecnológica, and Universidad Nacional de La Plata.

\section{REFERENCES}

Ameghino F. 1889. Contribución al conocimiento de los mamíferos fósiles de la República Argentina. Actas de la Academia Nacional de Ciencias de Córdoba 32: $1-10$.

Arslanov KA, Svezhentsev YS. 1993. An improved method for radiocarbon dating fossil bones. Radiocarbon 35(2):387-91.

Bonadonna FP, Leone G, Zanchetta G. 1995. Composición isotópica de los fósiles de gasterópodos continentales de la provincia de Buenos Aires. Indicaciones paleoclimáticas. Monografías del Museo Nacional de Ciencias Naturales 12:75-103.

Carbonari J, Figini A, Gómez G, Huarte R. 1980. Datación radiocarbónica de restos óseos fósiles. Resúmenes del Simposio sobre Problemas de la Geología Litoral Atlántica Bonaererense. Mar del
Plata. p 21-34.

Carbonari J, Figini A, Gómez G, Tonni E, Fidalgo F. 1987. Edades isotópicas de cetáceos fósiles de la Formación Las Escobas, NE de la provincia de Buenos Aires, Argentina. Actas del Décimo Congreso Geológico Argentino 3:179-83.

Cione AL, Tonni EP. 1995a. Chronostratigraphy and "Land mammal-ages" in the Cenozoic of southern South America: principles, practices and the "Uquian" problem. Journal of Paleontology 69:135-59.

Cione AL, Tonni EP. 1995b. El estratotipo de los pisos Montehermosense y Chapadmalalense (Plioceno) de esquema cronológico sudamericano. Ameghiniana 32: 369-74.

Cione AL, Tonni EP. 1996. Inchasi, a Chapadmalalan (Pliocene) locality in Bolivia. Comments on the 
Pliocene-Pleistocene continental scale of southern South America. Journal of South American Earth Sciences 9:221-36.

Cione AL, Tonni EP. 1999. Biostratigraphy and chronological scale of the uppermost Cenozoic of the Pampean area. In: Tonni EP, Cione AL, editors. Quaternary vertebrates of South America. Quaternary of South America and Antarctic Peninsula 12:23-52.

Cione AL, Tonni EP, Bond M., Carlini A, Pardiñas UFJ, Scillato Yané G, Vucetich MG, Verzi D. 1999. Occurrence charts of Pleistocene mammals in the Pampean area, eastern Argentina. In: Tonni EP, Cione AL, editors. Quaternary vertebrates of South America. Quaternary of South America and Antarctic Peninsula 12: 53-60.

Colado U, Figini A, Fidalgo F, Fuchs E. 1995. Los depósitos marinos del Cenozoico superior aflorantes en la zona comprendida entre Punta Indio y el río Samborombón, provincia de Buenos Aires. Actas de las Cuartas Jornadas Geológicas y Geofísicas Bonaerenses $1: 151-8$.

Dillon A, Rabassa J. 1985. Miembro La Chumbiada, Formación Luján (Pleistoceno, provincia de Buenos Aires): una nueva unidad estratigráfica del valle del río Salado. Actas de las I Jornadas Geológicas Bonaerenses 1:1-27.

Fasano J, Isla F, Mook W, van der Plasche O. 1987. Máximo transgresivo postglacial de 7000 años en Quequén, Provincia de Buenos Aires. Revista de la Asociación Geológica Argentina 43:475-7.

Fidalgo F. 1979. Upper Pleistocene- Recent marine deposits in northeastern Buenos Aires Province (Argentina). Proceedings of the 1978 International Symposium on Coastal Evolution in the Quaternary 3:38494

Fidalgo F. 1983. Algunas características de los sedimentos superficiales en la cuenca del río Salado y en la Pampa ondulada. Coloquio Internacional sobre Hidrología de grandes llanuras 1:1-19.

Fidalgo F. 1992. Provincia de Buenos Aires. Continental. In Iriondo M, editor. El Holoceno de Argentina Buenos Aires. Cadinqua. p 23-38.

Fidalgo F, Colado U, De Francesco F. 1973. Sobre ingresiones marinas cuaternarias en los partidos de Castelli, Chascomús y Magdalena (Provincia de Buenos Aires). Actas del Quinto Congreso Geológico Argentino 1:227-40.

Fidalgo F, Figini A, Gómez G, Carbonari J, Huarte R. 1981. Dataciones radiocarbónicas en las Formaciones Las Escobas y Destacamento Río Salado, provincia de Buenos Aires. Actas del VIII Congreso Geológico Argentino 4:43-56.

Fidalgo F, Meo Guzmán L, Politis G, Salemme M, Tonni EP. 1986. Investigaciones arqueológicas en el sitio 2 de Arroyo Seco (Pdo. de Tres Arroyos-Provincia de Buenos Aires, República Argentina). In: Bryan AL, editor. New evidence for the Pleistocene peopling of the Americas. Portland: University of Maine Press. p
221-69.

Fidalgo F, Riggi JC, Gentile R, Correa H, Porro N. 1991. Los "Sedimentos postpampeanos" continentales en el ámbito sur bonaerense. Revista de la Asociación Geológica Argentina 46:239-56.

Figini A. 1992. Edades ${ }^{14} \mathrm{C}$ de sedimentos marinos holocénicos de la provincia de Buenos Aires. Actas de las Terceras Jornadas Geológicas Bonaerenses 1:147-51.

Figini A, Carbonari J. 1994. Análisis de las dataciones radiocarbónicas en valvas de moluscos marinos. Actas del Décimosegundo Congreso Geológico Argentino y Segundo Congreso de Exploración de Hidrocarburos 2:245-48.

Figini A, Fidalgo F, Huarte R, Carbonari J, Gentile R. 1995. Cronología radiocarbónica de los sedimentos de la Formación Luján en Arroyo Tapalqué, provincia de Buenos Aires. Actas de las Cuartas Jornadas Geológicas y Geofísicas Bonaerenses 1:119-24.

Figini A, Gómez G, Huarte R. 1978. Aplicación de las dataciones por el método de Carbono-14 en el campo de la Geología del Cuaternario. Resúmenes de la Segunda Reunión Informativa del Cuaternario Bonaerense 1:35-40.

Figini A, Rabassa J, Tonni E, Huarte R, Gómez G, Carbonari J, Zubiaga A. 1985. Datación radiocarbónica de gasterópodos terrestres en sedimentos del Pleistoceno superior y Holoceno del valle del río Sauce Grande, provincia de Buenos Aires. Resúmenes de las Primeras Jornadas Geológicas Bonaerenses 1:131-2.

Figini A, Rabassa J, Tonni E, Huarte R, Gómez G, Carbonari J, Zubiaga A. 1989. Datación radiocarbónica de gasterópodos terrestres en sedimentos del Pleistoceno superior y Holoceno del valle del río Sauce Grande, Provincia de Buenos Aires. Resúmenes de las Primeras Jornadas Geológicas Bonaerenses 1:809-24.

Figini A, Huarte R, Carbonari, J, Tonni E. 1998. Edades C-14 en un perfil del arroyo Tapalqué, provincia de Buenos Aires, Argentina. Contribución a la cronología de acontecimientos faunístico-ambientales. Actas $X$ Congreso Latinoamericano de Geología y VI Congreso Nacional de Geología Económica: 27-31.

Follestad B, Omosi M. 1979. The C-14 age of the "Toten" mammoth, eastern Norway. Boreas 8:307-12.

Gómez G, Figini A, Fidalgo F. 1988. Secuencia vertical de edades ${ }^{14} \mathrm{C}$ en la Formación Las Escobas en la localidad de Cerro de la Gloria, Bahía de Samborombón, prov. de Buenos Aires, Argentina. Actas de las Segundas Jornadas Geológicas Bonaerenses 1:277-81.

Gómez G, Huarte R, Figini A, Carbonari J, Zubiaga A, Fidalgo F. 1985. Análisis y comparación de dataciones radiocarbónicas de conchas de moluscos de la Fm Las Escobas, provincia de Buenos Aires. Actas de las Primeras Jornadas Geológicas Bonaerenses 1:121-2.

Gómez G, Huarte R, Figini A, Carbonari J, Zubiaga A, Fidalgo F. 1989. Análisis y comparación de dataciones radiocarbónicas de conchas de moluscos de la Fm Las Escobas, provincia de Buenos Aires. Actas de las Primeras Jornadas Geológicas Bonaerenses 1:623-37. 
Hedges RE, van Klinken GJ. 1992. A review of current approaches in the pretreatment of bone for radiocarbon dating by AMS. Radiocarbon 34(3):279-91.

Huarte R, Carbonari J, Tonni E, Figini A. 1988. Dataciones ${ }^{14} \mathrm{C}$ de restos óseos fragmentados. Metodología para su mezcla. Actas del Simposio Internacional del Holoceno en América del Sur. Cadinqua:182-85.

Huarte R, Figini A. 1988. La Plata Radiocarbon Laboratory-liquid scintillation counting. Radiocarbon 30(3): $347-50$.

Huarte R, Figini A, Carbonari J, Gómez G, Zubiaga A. 1983. Dataciones radiocarbónicas del sitio Punta Hermengo (Partido de General Alvarado, Provincia de Buenos Aires). Ameghiniana 20:295-6.

Longin R. 1971. New method of collagen extraction for radiocarbon dating. Nature 230:241-2.

MacPhee R. 1999. Extintions in near time. New York: Klower Academic/Plenum Publishers. 394 p.

Martin PS, Klein R, editors. 1984. Quaternary extinctions. Tucson: The University of Arizona Press. 600 p.

Pardiñas UFJ, Gelfo J N, San Cristóbal J, Cione A, Tonni EP. 1996. Una tafocenosis de organismos marinos y continentales en el Pleistoceno superior en el sur de la provincia de Buenos Aires. Actas del XIII Congreso
Geológico Argentino y III Congreso de Exploración de Hidrocarburos 5:95-111.

Pascual R, Ortega Hinojosa E, Gondar D, Tonni E. 1965. Las edades del Cenozoico mamalífero de la Argentina, con especial atención a aquellas del Territorio Bonaerense. Anales de la Comisión de Investigaciones Científicas de la Provincia de Buenos Aires 6:165-93.

Rossello EA, Bor-Ming J, Liu TK, Petrocelli JL. 1999. New 4,300 YR ${ }^{14} \mathrm{C}$ age of glyptodonts at Luján river (Buenos Aires, Argentina) and its implications. Actas del Segundo Simposio Sudamericano de Geología Isotópica 1:105-10.

Stafford TW, Jull AJ, Brendel KK, Duhamel K, Donahue D. 1987. Study of bone radiocarbon dating accuracy at the University of Arizona (NSF) Accelerator Facility for Radioisotope Analysis. Radiocarbon 29(1):24-44.

Tonni E. 1990. Mamíferos del Holoceno en la provincia de Buenos Aires. Paula-Coutiana 4:3-21.

Zárate M, Espinosa M, Ferrero L. 1995. La Horqueta II, río Quequén Grande: Ambientes sedimentarios de la transición Pleistoceno-Holoceno. Actas de las Cuartas Jornadas Geológicas y Geofísicas Bonaerenses 1: 195-204. 